\title{
Climate change impacts on surface water resources in arid and semi-arid regions: a case study in northern Jordan
}

\author{
Nezar Hammouri ${ }^{1}$ (D) Jan Adamowski ${ }^{2}$ Muwaffaq Freiwan ${ }^{3} \cdot$ \\ Shiv Prasher ${ }^{2}$
}

Received: 18 December 2014/ Accepted: 5 February 2016/Published online: 19 February 2016

(C) Akadémiai Kiadó 2016

\begin{abstract}
Given Jordan's limited water resources and the doubling of its population over the last two decades, the gap between water demand and supply has been constantly increasing. Climate change is anticipated to worsen this situation by jeopardizing existing water resources. In the present study, SWAT was used to assess the impacts of climate change on water resources in the northern regions of Jordan. Global climate models (GCM) were used to assess the future impacts of climate change on water resources in the study area. The analyses of three different GCM-generated datasets indicate that stream flow rates are expected to decrease by up to $22 \%$ by the year 2080 . This decrease will be particularly severe in the months of maximum peak flow (February and March), perhaps reaching as much as 35-40 \%. A minor increase in stream flow rates is expected to occur in some months. Based on these results, impacts of climate change are projected to raise water deficits in Jordan. Therefore, it is crucial to review Jordan's 2008-2022 National Water Strategy.
\end{abstract}

Keywords Climate change impacts - Water resources - SWAT · Jordan - Stream flow · Surface hydrology

\section{Introduction}

With a current $110-150 \mathrm{~m}^{3}$ year $^{-1}$ per capita share of all-purpose water, compared to the international water poverty line of $1000 \mathrm{~m}^{3}$ year $^{-1}$ per capita, Jordan is the fourth poorest country in the world in terms of water resources (World Bank 2013). Water availability has declined from $3600 \mathrm{~m}^{3}$ year $^{-1}$ per capita in 1946 to $145 \mathrm{~m}^{3}$ year ${ }^{-1}$ per capita in 2007

Nezar Hammouri

nezar@hu.edu.jo

1 Faculty of Natural Resources and Environment, The Hashemite University, Zarqa 13115, Jordan

2 Department of Bioresource Engineering, Faculty of Agricultural and Environmental Sciences, McGill University, Ste Anne de Bellevue, Montreal, Canada

3 Meteorology and Climate Expert, Mideast Aviation Academy, Amman, Jordan 
(MWI 2009). Water for irrigation, in particular, represents $71 \%$ of the water demand and $64 \%$ of the water supply. Groundwater in Jordan having been overexploited for agricultural uses in the last two decades has resulted in a $151 \times 10^{6} \mathrm{~m}^{3}$ deficit in 2007 (MWI 2009).

The relatively high and rising consumption of available water resources over the last two decades is linked to the population growth rate, which reached about $2.5 \%$ in 2012 (DOS 2013) and added population growth due to unexpected geopolitical changes. For instance more than 1 million people were relocated to Jordan after the Second Gulf War in 1990. Furthermore, more than 1.5 million Syrian refugees have crossed the borders due to the current war in Syria. All these factors have imposed a substantial added pressure on already strained water resources resulting in unexpected increases in water demand.

According to Jordan's Water Strategy for the years 2008 to 2022 (MWI 2009), the deficit in the available water resources was approximately $45 \%$ in 2005 (Table 1), while the projected deficit in 2022 is expected to be around $30 \%$. This assumes that additional sources of water will be discovered and exploited and some mega projects will be implemented. Such projects include so-called Red-Dead Canal that would connect Red Sea with Dead Sea, another project is desalination, and also water harvesting projects are planned.

International studies, including reviews by the Intergovernmental Panel on Climate Change (IPCC 2000), have reported that arid areas, semi-arid areas and those currently suffering a scarcity of water resources (e.g., North Africa, the Middle East, and in particular Jordan) will be subject to even greater water deficits in the future, not only in terms of quantity, but also in terms of quality (IPCC 2008). Earlier regional and local studies relying on past weather records have shown an increase in mean temperatures and in the magnitude and frequency of extreme temperatures events (IPCC 2008). The IPCC Technical Report on Climate Change and Water Resources (2008) presents records and climate projections, which provide abundant evidence that climate change impacts threaten freshwater resources, and outlines how these might have wide-ranging consequences for human societies and ecosystems. Such climate change would also affect the function and operation of existing hydrological infrastructure, including hydropower, structural flood defenses, irrigation and drainage systems, as well as require updated water management practices.

A number of studies conducted in Jordan have sought to assess the potential impacts of climate change on the nation's water resources. In 1997, the First National Communication

Table 1 Water Budget for Jordan (MWI 2009)

\begin{tabular}{lrrrr}
\hline Year & 2005 & 2010 & 2015 & 2022 \\
\hline Available resources (MCM) & & & & \\
Ground water & 259 & 259 & 259 & 259 \\
Surface water & 382 & 404 & 419 & 433 \\
Reclaimed water & 34 & 69 & 89 & 101 \\
Others & 344 & 511 & 454 & 456 \\
Total & 1019 & 1244 & 1220 & 1250 \\
Required demands (MCM) & & & & \\
Urban, Industrial & 433 & 493 & 561 & 634 \\
Agriculture & 1114 & 1120 & 1101 & 1052 \\
Return flow from groundwater & 66 & 63 & 62 & 63 \\
Deficit & -461 & -306 & -371 & -373 \\
Deficit \% & 45 & 25 & 31 & 30 \\
\hline
\end{tabular}


Report to the United Nations Framework Convention on Climate Change (UNFCCC) under the theme of "Vulnerability and Adaptation to Climate Change" was published (GCEP 1997). In this report, simulations of future monthly water balance components, derived with the Surface-Infiltration-Base Flow model, showed that temperature increases would lead to lower annual mean and peak stream flows, although the timing of peaks would remain largely unaltered.

Jordan's Second National Communication to the UNFCCC (MEJ-UNDP, 2009) outlined the analysis of potential impacts of climate change on hydrological systems and water resources using the WEAP (Water Evaluation and Planning System) hydrological model. The analyses showed that, in general, across several possible future climate scenarios, stream flow rates would be strongly affected, dropping by as much as $30 \%$ within the next 50 years, when assuming a $20 \%$ drop in precipitation and $2{ }^{\circ} \mathrm{C}$ rise in temperature. By 2050 a $20 \%$ drop in flow rate would be expected in the rainy months of January and February, within the next 50 years, March flow rates might be expected to drop by $40 \%$.

Jordan's Third National Communication on Climate Change was released in 2014. According to this Report, the impact of the increased evaporation and decreased rainfall will result in less recharge and therefore less replenishment of surface water and groundwater reserves (MoEnv 2014).

According to the 2009 Arab Environment: Climate Change report (ADEP 2009), which described the potential impacts of climate change on water resources in Arab countries, anthropogenic problems, attributed the worsening situation in Jordan to the widespread construction of dams, unsustainable irrigation practices consuming $50 \%$ in excess of Jordanian water resources, as well as high rates of human water consumption. The expected effects of climate change are likely to exacerbate this situation. With continuing increases in temperature, water flow in the Euphrates and Jordan rivers are predicted to decrease by 30 and $80 \%$, respectively, by the year 2100 .

A study of Lioubimtseva and Henebry (2009) conducted to assess climatic and environmental changes in arid Central Asia, found that aridity was expected to increase across the entire Central Asian region, and particularly in the western portions of Turkmenistan, Uzbekistan, and Kazakhstan. Temperature increases were projected to be particularly high in the summer and fall, accompanied by decreases in precipitation (Lioubimtseva and Henebry 2009). A similar study on the impacts of climate change and anthropogenic alterations in land-cover on arid lands in central Asia, found that such alterations could significantly modify surface albedo, water exchange and nutrient cycles, and, in turn, influence both regional and global climatic systems (Lioubimtseva et al. 2005).

There is a strong necessity for further research into the possible impacts of climate change on water resources in Jordan. As such, the present study aims at assessing the impacts of climate change on water resources, by using the Soil and Water Assessment Tool (SWAT) model to simulate one of the most important watersheds in Jordan (Yarmouk Basin) under different future climate scenarios.

\section{Study area}

The Yarmouk River basin spans the northern part of Jordan and southern part of western Syria, emptying into the Jordan River near Adasiyia, Jordan (Fig. 1). The river thus drains flood and base flows from both Jordanian and Syrian territory. The river's total catchment area covers $6790 \mathrm{~km}^{2}$. Among these, only $20 \%$ of this total area are located within 


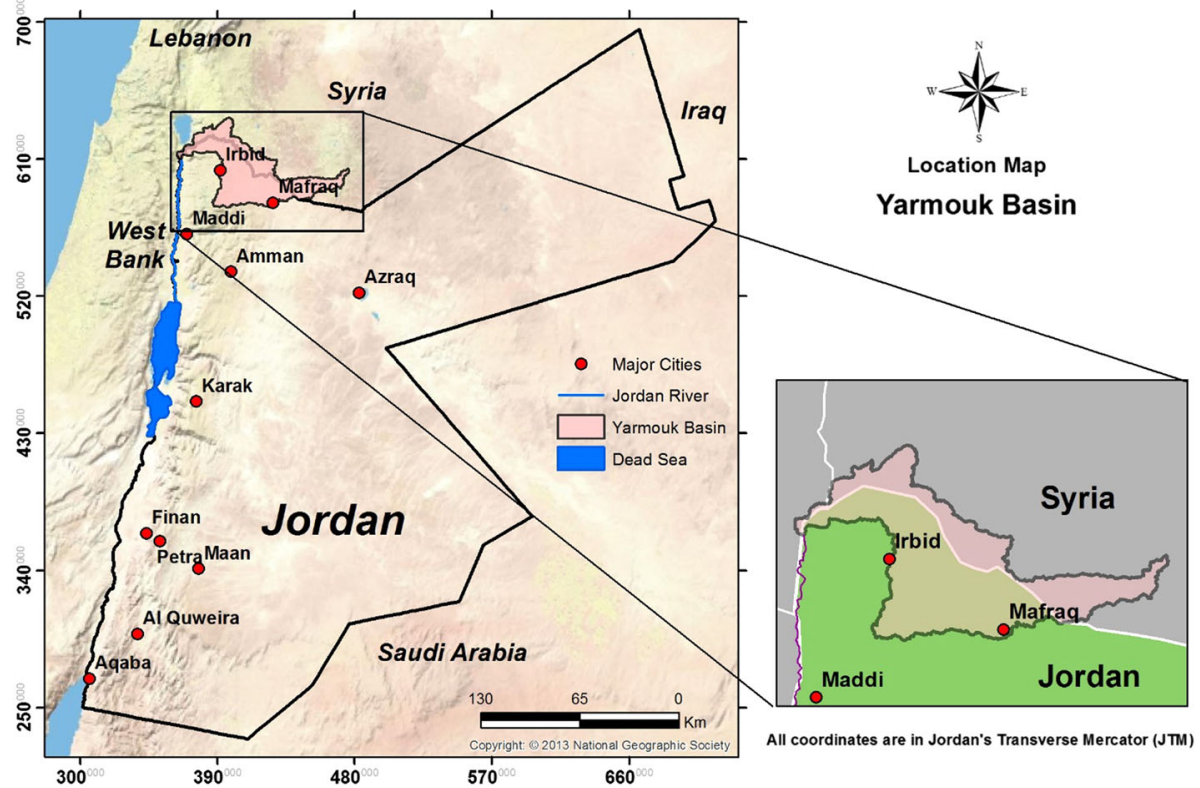

Fig. 1 Geographical location of the Yarmouk River Basin within Jordan

Jordan's area (MEJ-UNDP 2009). Based on data from the Earth Remote Sensing Data Analysis Center (ERSDAC), elevation ranged from $-328 \mathrm{~m}$ at the outlet of the Yarmouk Basin to $1786 \mathrm{~m}$ in the western highlands.

Yarmouk Basin has the semiarid climate of the Mediterranean Sea region with a limited amount of rainfall and high temperatures. The mean annual rainfall is about $410 \mathrm{~mm}$, while mean annual temperatures is about $18{ }^{\circ} \mathrm{C}$, respectively (Rakad et al. 2007).

About $60 \%$ of the Yarmouk basin's agricultural lands are rainfed, and $20 \%$ are irrigated. Roughly $11 \%$ of the basin area is open rangeland, $6 \%$ is urbanized, and $2 \%$ is protected as a natural reserve. Due to over-pumping of groundwater and the construction of dams in Syria's portion of the basin, the river witnessed a sharp drop in base flow in Jordan's northwest, during the late 1990s and early 2000s. Currently, the summer base flow of this river is about $158 \mathrm{MCM}$ (MoEnv 2009).

\section{Methodology}

Climate, topography, soil and land use data were collected and downloaded to allow the calibration and validation of the GIS-assisted ArcSWAT model based on current conditions in the basin (i.e., baseline scenario). The three Global Climate Model (GCM) models best suited to the study area served to provide separate predicted climate data under different land management options for the ArcSWAT model. The validated SWAT model and using future climatic data will provide an assessment of the impacts of climate change on water resources of the study area.

The adopted methodology to achieve this study objective is illustrated in Fig. 2. 


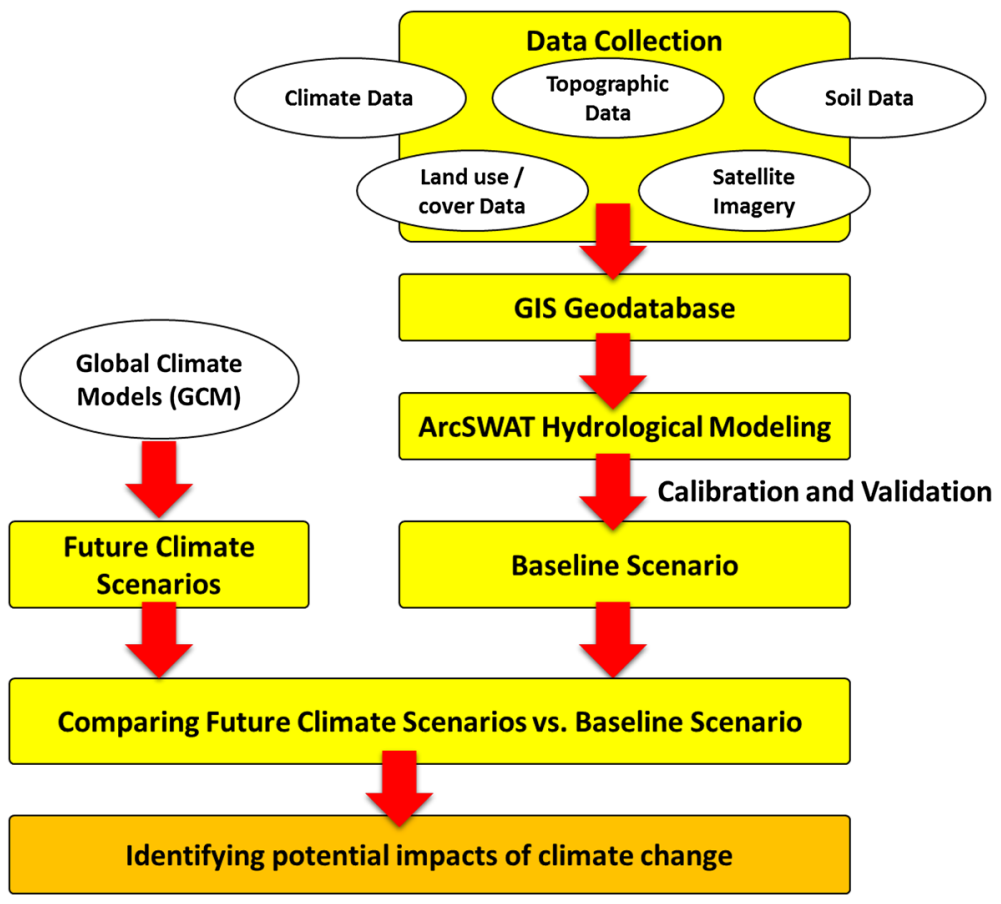

Fig. 2 Methodology adopted to assess the impacts of climate change in Jordan's Yarmouk River basin

\section{Data collection}

Different data sets were collected, including:

a) Digital Elevation Model (DEM): A DEM was downloaded from the Earth Remote Sensing Data Analysis Center (ERSDAC) website (http://www.gdem.aster.ersdac.or.jp/). The data were of the ASTER GDEM type, with a spatial resolution of $30 \mathrm{~m}$ (Fig. 3).

b) Soil Data: Soil information was obtained from Ministry of Agriculture for the study area. A soil texture map with five soil groups was prepared including Clay Loam (CL), Clay (C), Silty Clay (SiC), Silty Clay Loam (SiCL) and Silty Loam (SiL) as defined by USDA soil classification nomenclature (Fig. 4).

c) Landsat ETM + Imagery: This imagery served in visual and digital interpretation to obtain land use information for the study area. Two Landsat scenes were downloaded from the USGS Earth Resources and Science Center (EOS) (http://glovis.usgs.gov/). PCI Geomatica was used to perform supervised classification for the downloaded Landsat ETM + Images. As a result, Yarmouk basin was classified into five major land use types (Fig. 5), these are (1) Rangeland, (2) Rain fed agriculture, (3) irrigated agriculture (4) Urban, and (5) Water Bodies. The western and the northwestern portions of the study area house over $90 \%$ of the basin's agricultural activities and vegetation. Agricultural lands, forested lands and pasturelands are concentrated in the western part of Yarmouk basin. Significant urban areas can be found in the northwestern portion of the Yarmouk basin (e.g., Irbid City, the second largest city in Jordan, as well as the city of Ramtha city). Barren lands can be found in the eastern portion of the basin. 


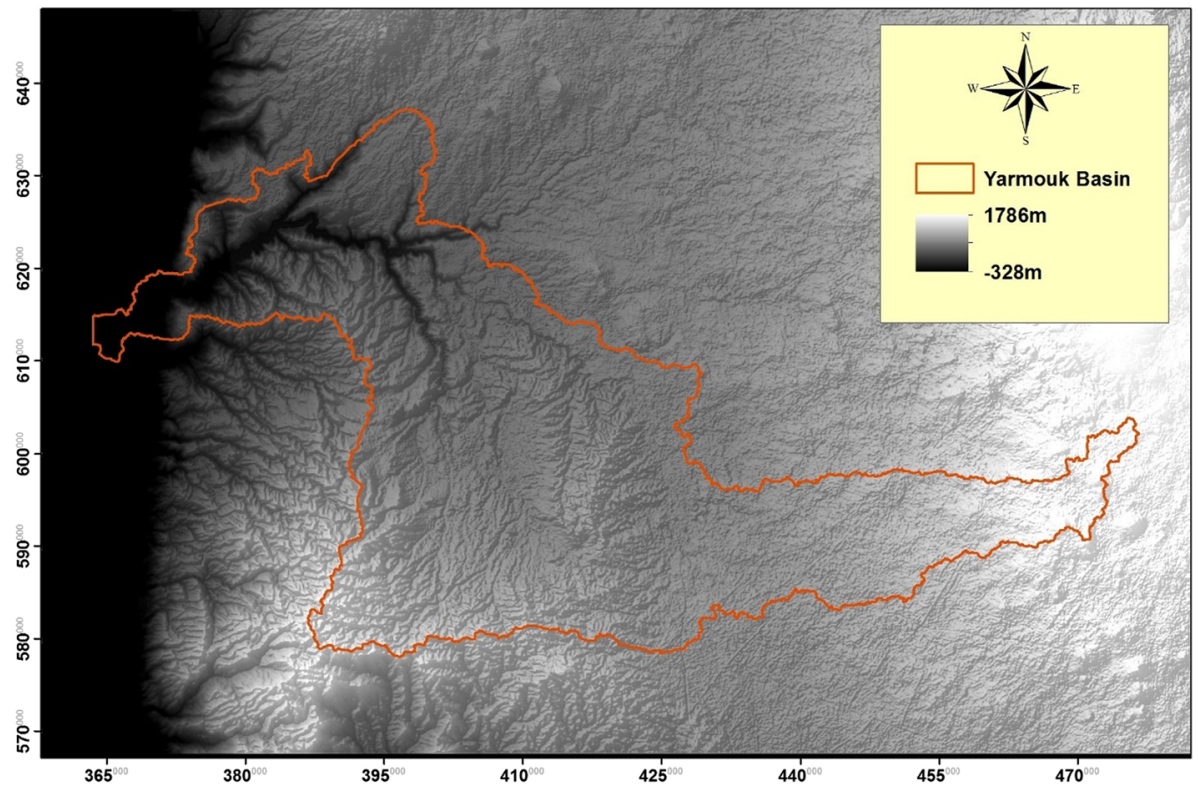

Fig. 3 ASTER GDEM-derived elevation map for the Yarmouk River basin

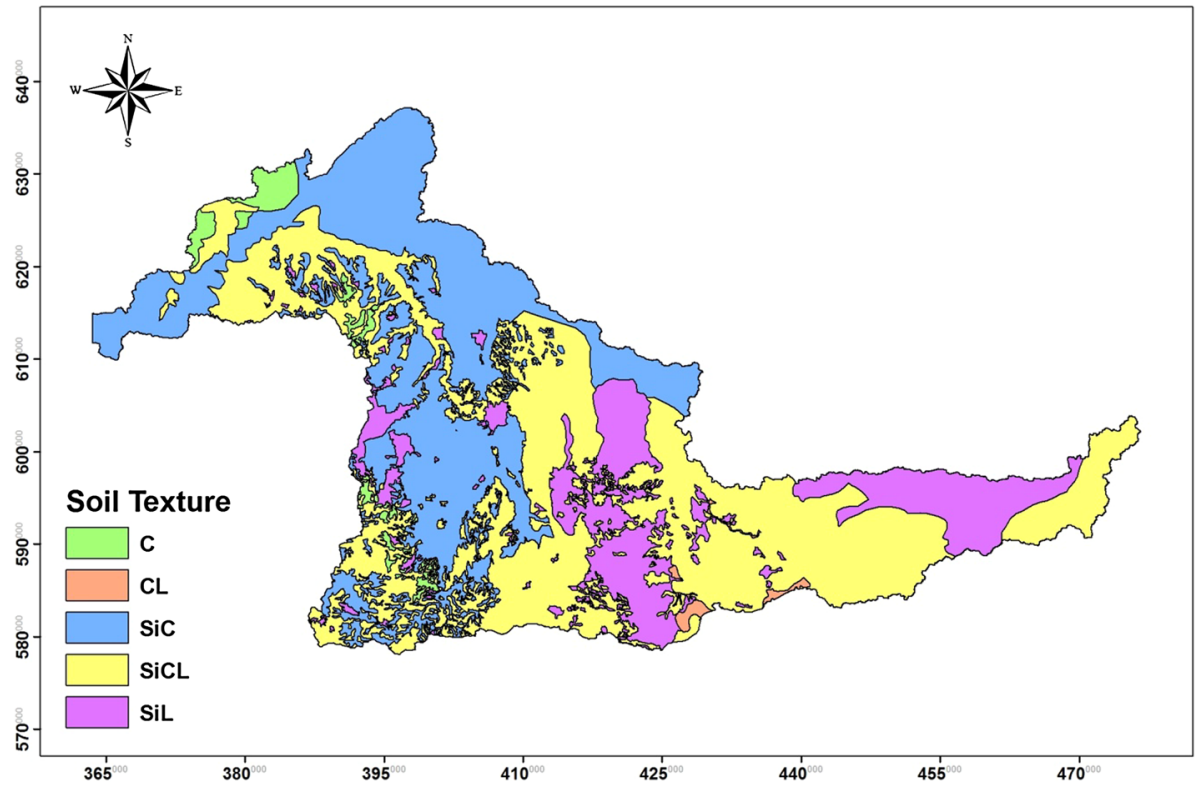

Fig. 4 Soil classification map for the Yarmouk River basin based on texture ( $C$ Clay, $C L$ Clay Loam, $S i C$ Silty Clay, SiCL Silty Clay Loam, SiL Silty Loam)

d) Meteorological Data: This included daily precipitation, temperature, and stream flow gauges for calibration purposes. Figure 6 shows the different gauges used in this study. 


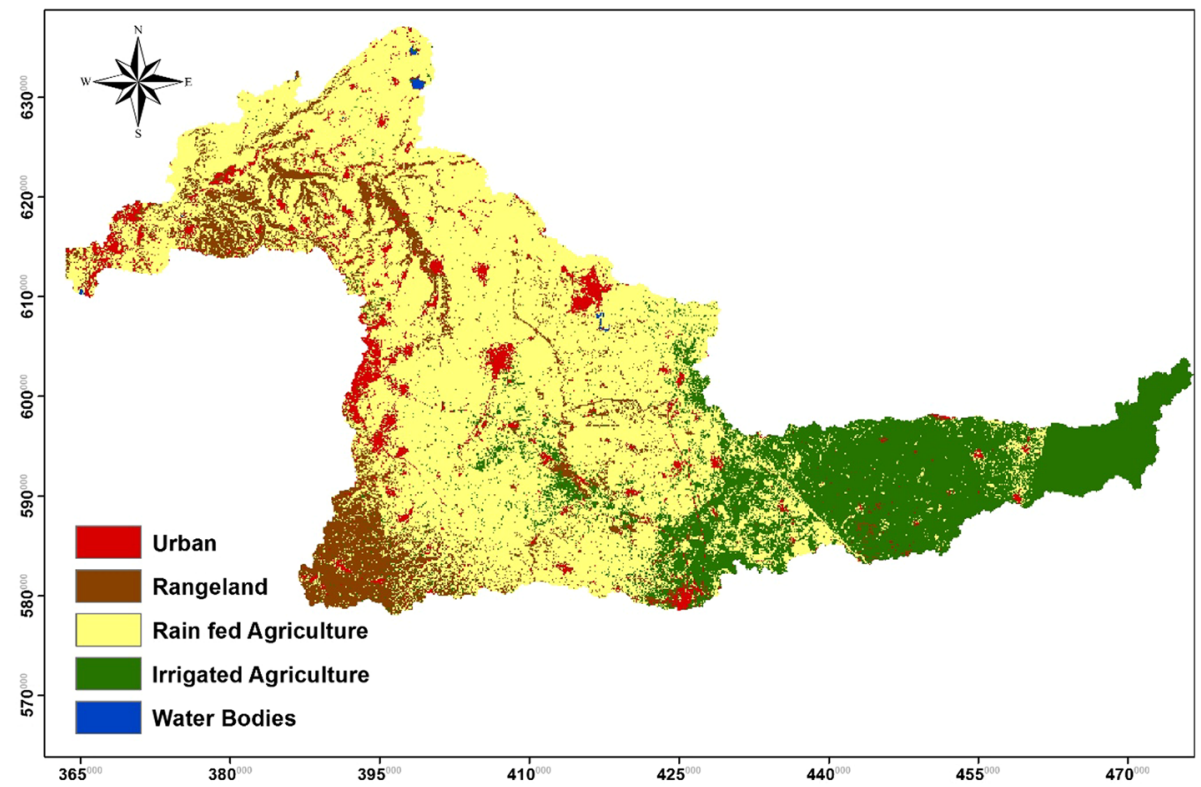

Fig. 5 Land use/land cover map for the the Yarmouk River basin, based on Landsat ETM+ image dated April 2002

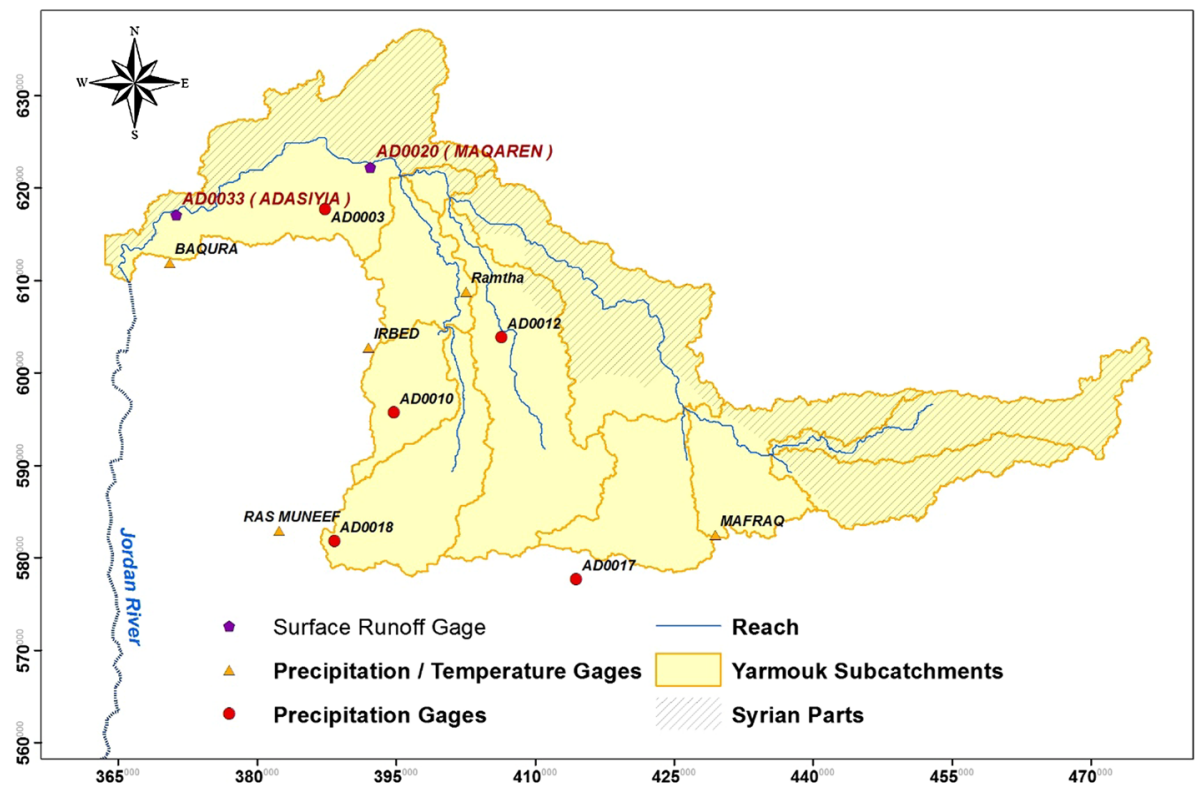

Fig. 6 Precipitation, temperature and surface flow gauging stations in the Yarmouk Basin

e) General Circulation Models (GCM) Data: GCMs are numerical models representing physical processes in the atmosphere, ocean, cryosphere and land surface. These models are the most advanced tools currently available for simulating the response of 
the global climate system to increasing greenhouse gas concentrations (IPCC 2008).

Three types of GCM data sets were downloaded and used in this study.

\section{Hydrological modeling using SWAT}

The Soil and Water Assessment Tool (SWAT), a watershed-scale simulation model developed by the United States Department of Agriculture-Agricultural Research Service (USDA-ARS), was developed to predict the impact of land management practices on water, sediment and agricultural chemical yields in large, complex watersheds with varying soils, land use and management conditions, over long periods of time. The model is physically-based and rather than incorporating regression equations to describe the relationship between input and output variables, SWAT requires specific information about weather, soil properties, topography, vegetation, and land management practices occurring in a watershed (Neitsch et al. 2005). The physical processes associated with water movement, sediment movement, crop growth, nutrient cycling, etc. are directly modeled by SWAT, using the input data. A continuous-time model (i.e., a long-term yield model), SWAT is regularly updated, the latest version having been released in 2009 (SWAT 2009). ArcSWAT is an ArcGIS-ArcView extension and graphical user input interface for the SWAT model (Neitsch et al. 2005). ArcSWAT facilitates the preparation of all the required input files to run the SWAT model and to extract the output results to project databases, and display them.

The hydrologic cycle as simulated by SWAT is based on the water balance equation:

$$
S W_{t}=S W_{o}+\sum_{i=1}^{t}\left(R_{\text {day }}-Q_{\text {surf }}-E_{a}-w_{\text {seep }}-Q_{g w}\right)
$$

where $t$ time (days), $w_{\text {seep }}$ quantity of seepage, i.e., water entering the vadose zone from the soil profile on day $i\left(\mathrm{~mm} \mathrm{H}_{2} \mathrm{O}\right), E_{a}$ quantity of evapotranspiration on day $i\left(\mathrm{~mm} \mathrm{H}_{2} \mathrm{O}\right), Q_{g w}$ quantity of return flow on day $i\left(\mathrm{~mm} \mathrm{H}_{2} \mathrm{O}\right), Q_{\text {surf }}$ quantity of surface runoff on day $i(\mathrm{~mm}$ $\left.\mathrm{H}_{2} \mathrm{O}\right), R_{\text {day }}$ quantity of precipitation on day $i\left(\mathrm{~mm} \mathrm{H}_{2} \mathrm{O}\right), S W_{t}$ final soil water content $(\mathrm{mm}$ $\left.\mathrm{H}_{2} \mathrm{O}\right), S W_{O}$ initial soil water content, day $i=0\left(\mathrm{~mm} \mathrm{H}_{2} \mathrm{O}\right)$.

SWAT has been widely used to assess the impacts of climate change on water resources. Wang et al. (2012) have used SWAT to assess the impact of climate change on stream flow in the arid Shiyang River Basin of northwest China. This study reveals that mean monthly stream flow in the Shiyang River Basin would increase in the 2020s, 2050s and 2080 s by between 0.7 and $6.1 \%$ at the Zamu gauging station, and by $0.1-4.8 \%$ at the Xiying gauging station. Monthly minimum streamflow were expected to increase persistently; however, while they increased in the 2020s, they subsequently decreased slightly in the 2050s and 2080s. Abouabdillah et al. (2010) also using SWAT, modelled the impact of climate change in a Mediterranean catchment (Merguellil, Tunisia). The main results from this study indicated severe impacts on available water resources as a result of increased temperature and reduced rainfall. Furthermore, the model predicted more intense drought events.

Ashraf et al. (2013) used SWAT to analyze the impact of climate change on water resource components, drought and wheat yield in a semiarid region: the Karkheh River Basin in Iran. Their study showed an increase of up to $25 \%$ in both frequency and length of dry periods in the study area, whereas increasing flood events could be expected in the 
northern and western parts of the region. Authors concluded that the impact of climate change would vary across the region, with some areas experiencing net negative impacts and others net positive impacts.

These studies indicate that SWAT model was efficient in simulating hydrological process in arid and semi-arid areas. Furthermore, SWAT was applied successfully in these studies to assess the impacts of climate change on water resources. However, and to ensure a successful implantation of SWAT, results always should be verified against measured observation from the field, as for example, measured stream flow values from stream flow gauges.

SWAT provides two methods for estimating stream flow rate: the SCS (Soil Conservation System) curve number procedure (SCS 1972) and the Green and Ampt infiltration method (Green and Ampt 1911). Due to data availability constraints, the SCS curve number was used in this study.

Baseline was created by using ArcSWAT. The time domain for the baseline scenario extends from $1 / 1 / 1972$ to $31 / 12 / 1999$. This period contains dry, wet, and normal flood flow years. For calibration purposes, the period from 1/1/1972 to 31/12/1990 was used, while the period from $1 / 1 / 1991$ to $31 / 12 / 1999$ was used for validation purposes. The SWAT model contains a large number of parameters generally drawn or estimated from the ArcSWAT database. Sensitivity analysis was performed to consider the most sensitive parameters for calibration process (Table 2).

Calibration was performed using monthly observed flow data measured at station AD0033 located in the downstream portion of the basin. The results of the automated calibration of SWAT (Fig. 7) show a good match between simulated and observed monthly surface flows. The mean monthly simulated flow for the calibration period (1972-1990) was $5.1 \mathrm{~m}^{3} \mathrm{~s}^{-1}$, which is similar to the observed mean stream flow during this period. Simulation results for the validation period (1991-1998) on a monthly (Fig. 7) and annual basis (Fig. 8) show a good match.

To better judge the quality of the calibrated model's output, the model performance statistics of root mean square (RMSE) and Nash-Sutcliffe model efficiency coefficient (NSE) were calculated. The RMSE represents the average magnitude of model errors when comparing predicted and observed values (Everitt 2002), but does not give any information on the direction of the error (i.e., over- vs. under-estimation). RMSE is given as (ArcGIS 10 Geostatistical Analyst Manual):

Table 2 Parameters used in SWAT model calibration

\begin{tabular}{|c|c|c|c|c|c|c|}
\hline \multirow[t]{2}{*}{ Name } & \multirow[t]{2}{*}{ Definition } & \multirow[t]{2}{*}{$\begin{array}{l}\text { Estimated } \\
\text { value }\end{array}$} & \multirow[t]{2}{*}{$\begin{array}{l}\text { Calibrated } \\
\text { value }\end{array}$} & \multirow[t]{2}{*}{ Units } & \multicolumn{2}{|c|}{$\begin{array}{l}\text { Possible } \\
\text { range }\end{array}$} \\
\hline & & & & & Min & $\operatorname{Max}$ \\
\hline $\mathrm{CN} 2$ & Curve number & 80.1 & 82.6 & - & 0 & 100 \\
\hline SOIL_ALB & Moist soil albedo & 0.21 & 0.81 & - & 0 & 1 \\
\hline EPCO & Plant uptake compensation factor & 0.41 & 0.95 & Inches & 0 & 1 \\
\hline ESCO & Soil evaporation compensation factor & 0.099 & 0.1200 & Inches & 0 & 1 \\
\hline SOIL_K & Saturated hydraulic conductivity & 0.9100 & 0.9100 & $\mathrm{~mm} / \mathrm{hr}$ & 0 & 2000 \\
\hline CANMX & Maximum canopy storage $\left(\mathrm{mm} \mathrm{H}_{2} \mathrm{O}\right)$ & 0.186 & 0.27 & $\mathrm{~mm}$ & 0 & 2.5 \\
\hline REVAPMN & $\begin{array}{l}\text { Threshold depth of water in the } \\
\text { shallow aquifer }\end{array}$ & 0.13 & 0.65 & $\mathrm{~mm}$ & -1 & 1 \\
\hline
\end{tabular}




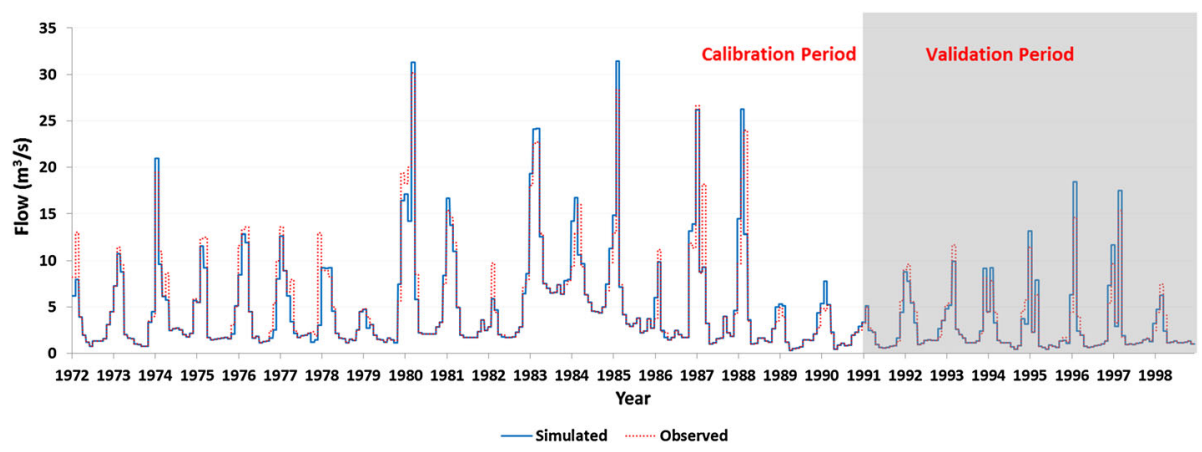

Fig. 7 Simulated (blue) and observed (red) total monthly flows in the Yarmouk Basin for the SWAT model's calibration (1972-1990) and validation (1991-1998) periods

$$
\mathrm{RMSE}=\sqrt{\frac{\sum_{i=1}^{n}\left(X_{\mathrm{obs}, i}-X_{\mathrm{model}, i}\right)^{2}}{n}}
$$

where $i$ represents an increment of time or place, $n$ is the total number of observed or modelled values, $X_{o b s, i}$ is the $i$ th observed value, in this case discharge, and $X_{\text {model, } i}$ is the $i$ th modelled value for discharge.

The RMSE can range from 0 to $\infty$, with 0 being a perfect score. The RMSE value was 0.25 for the calibration period and 0.28 for the validation period. Figure 9 shows simple correlation coefficients between simulated and observed time series (both for the calibration and the validation periods). As seen from this figure, the correlation coefficient $\left(\mathrm{R}^{2}\right)$ between these values is about 0.9 which indicates a high correlation between simulated and observed stream flow values.

The Nash-Sutcliffe efficiency coefficient (NSE), commonly used to assess the predictive accuracy of hydrological models, is given as (Nash and Sutcliffe 1970):

$$
N S E=1-\frac{\sum_{t=1}^{T}\left(Q_{o}^{t}-Q_{m}^{t}\right)^{2}}{\sum_{t=1}^{T}\left(Q_{o}^{t}-\overline{Q_{o}}\right)^{2}}
$$

where $Q_{o}^{t}$ is the observed discharge at time $t, Q_{m}^{t}$ is the modeled discharge at time $t, \overline{Q_{0}}$ is the mean observed discharge, and $T$ is the number of observed (and thus modeled) discharge values.

The NSE can range from $-\infty$ to 1 , where $N S E=1$ represents a perfect match of modeled to observed discharge. $N S E=0$ represents a case where the models performs no better than using $\overline{Q_{0}}$ as the predicted value for all predicted values, and increasingly negative NSE values represent increasingly poor model performance. Values of NSE were 0.91 for the calibration period and 0.86 for the validation period, indicating that the simulated values match the observed values quite well.

\section{Assessment of climate change impacts on water resources}

To assess the impacts of climate change on water resources in the Yarmouk basin, the Global Climate Model (GCM) was used to generate future climate data records. 


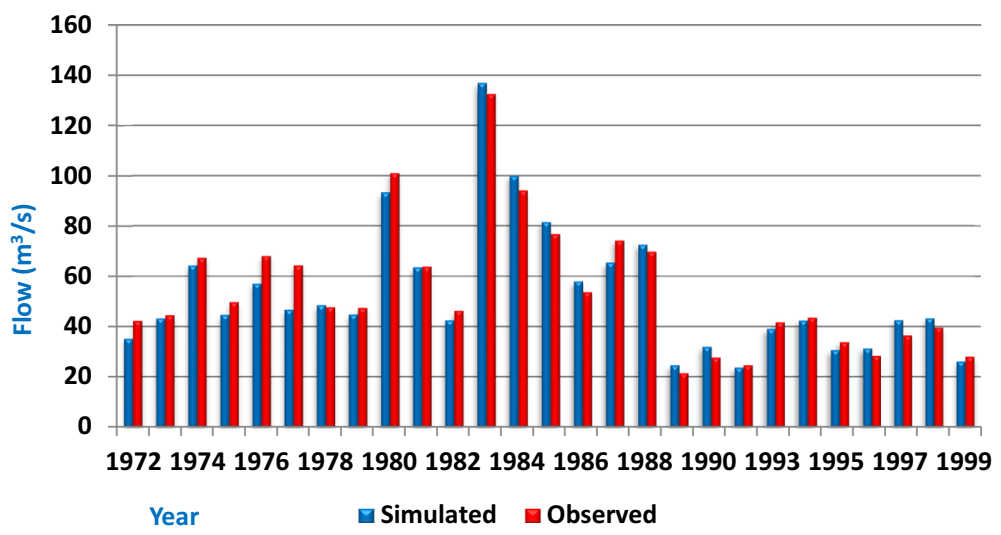

Fig. 8 Annual values of simulated flow discharges compared with the observed values
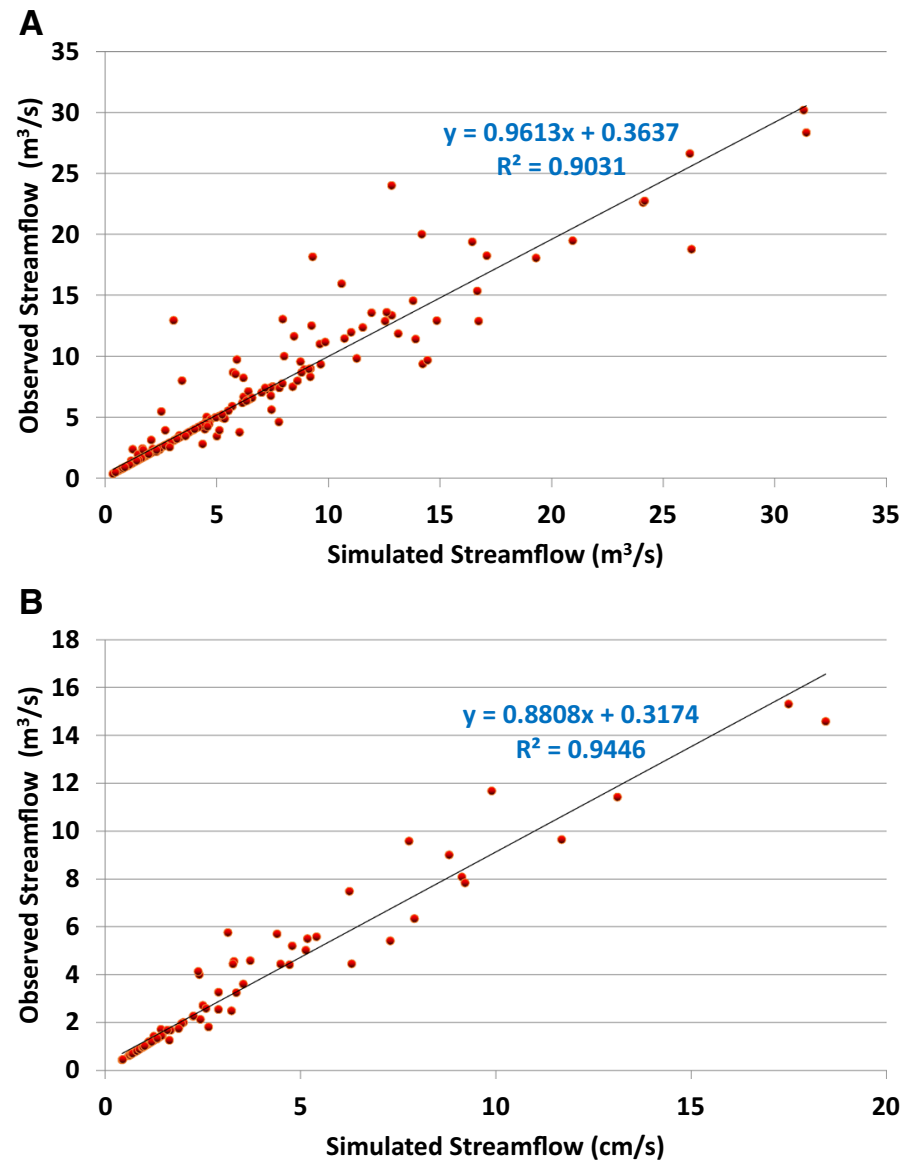

Fig. 9 Scatter plot and trend line for observed versus SWAT-simulated stream flow in the Yarmouk Basin for a calibration period (1972-1990) and b Validation Period (1991-1999) 


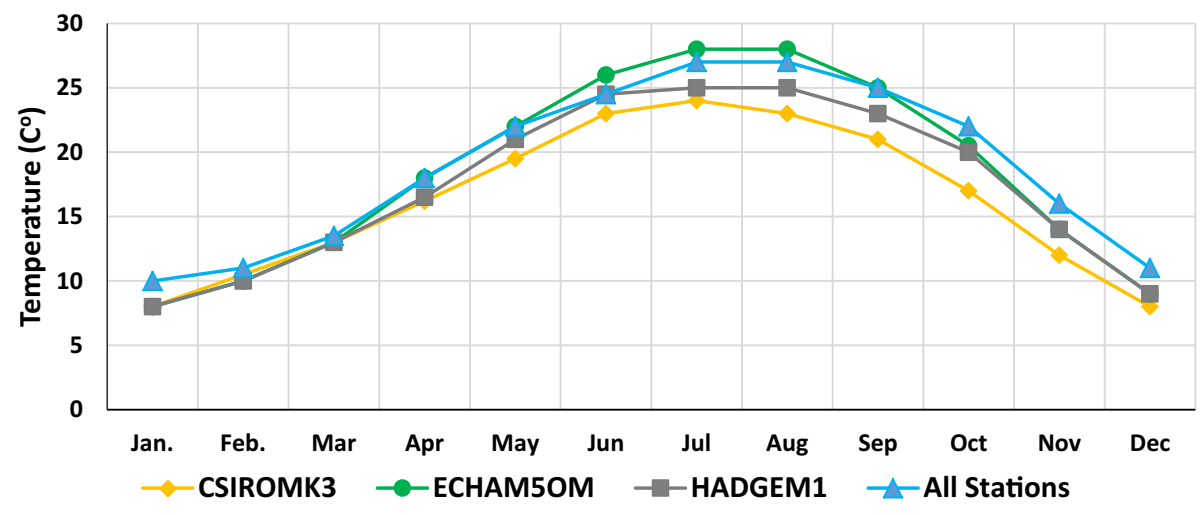

Fig. 10 Comparison of the mean temperature prediction scenarios of three GCM models and the current average mean temperature at the observation stations in the in the study area (1961-2000) (MEJ-UNDP 2009)

Climate change scenarios describe plausible future changes in terms of climate variables which are usually compared to baseline (current) climate conditions. The most common approach to derive climate change scenarios is to make use of one of three types of increasingly complex climate model outputs: (i) Simple Climate Models, (ii) General Circulation Models, or Global Climate Models (GCMs) or (iii) Regional Climate Models (RCMs). In this study, temperature and precipitation outputs of 13 GCMs over the period of 1961-2005 were downloaded from the Canadian Climate Change Scenarios Network website (http://www.cccsn.ec.gc.ca/). According to Jordan's Second National Communication to the United Nations Framework Convention on Climate Change (MEJ-UNDP, 2009), there are three GCM models that best match Jordan's climatological records. These include the (i) CSIROMK3 model developed by the Commonwealth Scientific and Industrial Research Organization (CSIRO), Australia, (ii) ECHAM5OM model, the 5th generation of the ECHAM general circulation model developed by the Max Planck Institute for Meteorology, Germany, and (iii) HADGEM1, the Hadley Center Global Climate Model, developed in the UK. For these three models SRES A2 climate models scenarios were used where regional economic development, high population growth and slow technological change are assumed (IPCC 2010). Future climate data from these models were downloaded on daily time scale to cover the period from 2010 to 2060 .

Daily precipitation, minimum and maximum temperature data from these three models where downscaled using a Statistical Downscaling Model (SDSM), a decision support tool developed to assess local climate change impacts, using a robust statistical downscaling technique (Wilby and Dawson 2004).

Figure 10 shows a comparison of predicted mean monthly temperature using three GCM models against mean monthly measured temperature at Yarmouk Basin (MEJ-UNDP 2009).

\section{Results and discussion}

Global Climate Models were used in this study to generate future climate records for the next 50 years (2010-2060) for the Yarmouk basin study area. These data were used as inputs to the calibrated and validated SWAT model to assess the impacts of climate change 


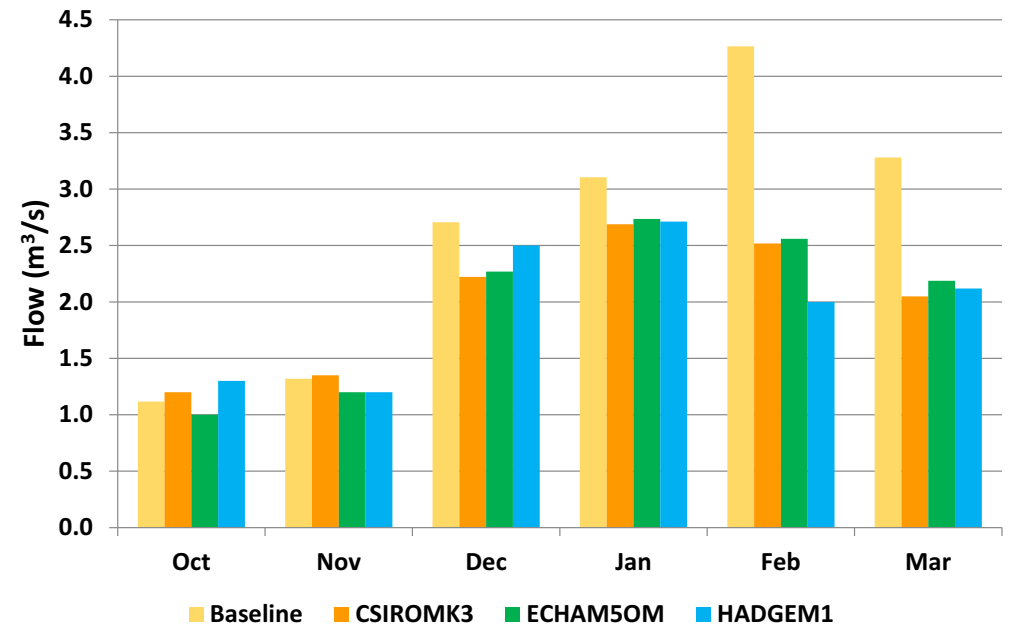

Fig. 11 Comparing monthly surface runoff in the Yarmouk Basin for three GCM-derived future climate scenarios (2010-2060) compared to the current baseline scenario (1972-1999)

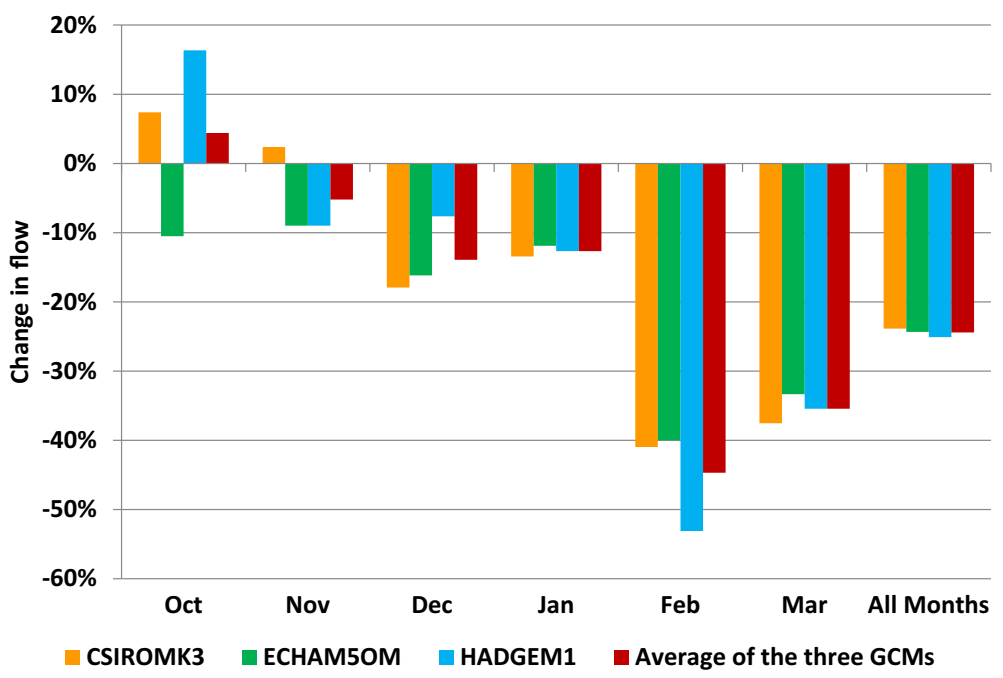

Fig. 12 Mean monthly percent difference from baseline flow for three GCM scenarios for the Yarmouk Basin, and mean percent difference across GCM scenarios (2010-2060)

on water resource of the study area. Each GCM scenario generated one set of stream flow predictions for the Yarmouk basin.

The three GCM models' simulated stream flows were compared directly (Fig. 11) and on a percentage basis (Fig. 12) to those under the baseline scenario. Despite using three different GCM climate models, similar results were obtained. Various magnitudes of decline in surface flow rates were expected in different months. The CSIROMK3 model predicts a major decrease in stream flow rates in February (about $41 \%$ ), $37 \%$ in March, $18 \%$ in December and $13 \%$ in January. The model also predicts an increase in stream 
flow in November (2\%) and October (7\%). The net change for rainy months according to this model is $24 \%$ decrease in stream flow rates. For the German model, ECHAM5OM, results similar to those of the CSIROMK3 model were obtained, except for October and November, where the model expect a decrease in stream flow rates with $10 \%$. The maximum drop is also expected in February (also roughly $40 \%$ ). For the entire rainy season, the net flow is projected to drop by $22 \%$. For the British model, HADGEM1, projected results are more catastrophic. For February, $50 \%$ of the flow rates will decrease. For March, the three GCM models combined predict a drop in stream flow of $30 \%$. The HADGEM1 model predicted a $16 \%$ rise in flow in October. Across the three GCMs maximum drops in the surface flow rates are expected for February and March (45 and $35 \%$ respectively). A minor $(<5 \%)$ increase is expected in October and November. The three models projected that the net flow will drop by $22 \%$ for the entire rainy season.

\section{Conclusion}

Given Jordan's limited water resources, the critical of water resources situation in Jordan could become even more complicated in consequence of the potential impacts of climate change. This study aims at assessing the impacts of climate change on water resources for one of the most important watersheds in Jordan, the Yarmouk Basin. To achieve this objective, the SWAT model was used along with ArcGIS software.

The baseline SWAT model was calibrated using observed data obtained from a runoff gauge station in the basin. The calibrated model's accuracy was tested using the RMSE and NSE statistics, showing the model outputs to closely match the observed flow values. Future climatic data were required to assess the impacts of climate change on water resources in the Yarmouk Basin.

To assess the impacts of climate change of surface flow rates of the study area, three GCM models were used to supply SWAT climatic input data: CSIROMK3, ECHAM5OM and HADGEM1. Future flow rates were predicted to drop by an average of $22 \%$ across the three GCMs. Such a situation would increase the stress on the already highly stressed water resources in Jordan.

In light of this, it is necessary to revise Jordan's current water budget (Table 1) to consider these changes in the budget. Furthermore, it is indispensable for Jordan to reconsider policies and strategies to assist the country adapt to the impacts of climate change and to reflect on these strategies and policies in the context of Jordan's National Water Strategy which was initiated in 2008 and involves planning through 2022.

As shown in this study, SWAT is an effective multi-purpose tool that could be used in assessing of climate change impacts on water resources. Therefore, SWAT is recommended in future studies of other watersheds in Jordan with different characteristics. This will help planners and decision-makers in Jordan's water sector and in adjacent countries to better manage their water resources while taking into account the varied impacts of climate change. It is suggested that in future studies in Jordan, SWAT be linked with other water management tools (e.g., WEAP or STELLA- modeling and simulation software). Through such links, SWAT would provide these tools with the necessary inputs by using different climate change scenarios.

Acknowledgments The authors would like to express their deep appreciation to the Arab Fund for Economic and Social Development for supporting this research and funding the first author's (Dean of Research, The Hashemite University, Jordan) sabbatical leave They also wish to thanks McGill University's 
Department of Bioresource Engineering for hosting this research, as well as Dr. Wael Zuraiq at The Hashemite University for language revision.

\section{References}

Abouabdillah A, Oueslati O, De Girolamo AM, Lo Porto A (2010) Modelin the impact of climate change in a Mediterranean catchment (Merguellil, Tunisia). Fresenius Environ Bull 19(10a):2334-2347

Ashraf Vaghefil S, Mousavil SJ, Abbaspour KC, Srinivasan R, Yang H (2013) Analyses of the impact of climate change on water resources components, drought and wheat yield in semiarid regions: Karkheh River Basin in Iran. Hydrol Proces (Online pre-publication) doi: 10.1002/hyp.9747

Department of Statistics, Kingdom of Jordan (DOS) (2013) Jordan Statistical Yearbook 2012. Amman, Jordan: Department of Statistics Kingdom of Jordan. http://www.dos.gov.jo/dos_home_a/main/ yearbook_2012.pdf. Viewed 16 Oct 2013

GCEP: The General Corporation for the Environment Protection, Kingdom of Jordan (GCEP) (1997) Initial Communication Report under the UN Framework Convention on Climate Change. Volume I. Executive Summary (revised Nov 1997), Ministry of the Environment, Amman. http://unfccc.int/resource/ docs/natc/jornc1.pdf. Viewed 16 Oct 2013

Green WH, Ampt GT (1911) Studies on soil physics, Part I, The flow of air and water through soils. J Agric Sci 4(1):1-24. doi:10.1017/S0021859600001441

Intergovernmental Panel on Climate Change (IPCC) (2000) IPCC Special Report Emissions Scenarios. A special report of IPCC Working Group III, at Available online at: A Special Report of IPCC Working Group III

Intergovernmental Panel on Climate Change (IPCC) (2008) Climate Change and Water. In: Bates BC, Kundzewicz ZW, Wu S, Palutikof JP (eds) IPCC Secretariat, Geneva, 210 pp. http://www.ipcc.ch/pdf/ technical-papers/climate-change-water-en.pdf. Viewed 16 Oct 2013

Intergovernmental Panel on Climate Change (IPCC) (2010) IPCC Special report on emissions scenarios. In: Nakicenovic N, Swart R (eds) Cambridge University Press, London. http://www.ipcc.ch/ipccreports/ sres/emission/index.php?idp=0. Viewed 16 Oct 2013

Lioubimtseva E, Henebry GM (2009) Climate and environmental change in arid Central Asia: impacts, vulnerability, and adaptations. J Arid Environ 73(11):963-977 pp. doi: 10.1016/j.jaridenv.2009.04.022

Lioubimtseva E, Cole R, Adams JM, Kapustin G (2005) Impacts of climate and land-cover changes in arid lands of Central Asia. J Arid Environ 62(2):285-308. doi:10.1016/j.jaridenv.2004.11.005

Ministry of Water and Irrigation (MWI) (2009). Water for life: Jordan's water strategy 2008-2022. Ministry of Water and Irrigation, Amman. http://web.idrc.ca/uploads/user-S/12431464431JO_WaterStrategy09.pdf. Viewed 16 October 2013

MoEnv: Ministry of Environment (2014) Jordan's Third National Communication to the UNFCCC. United Nations Development Programme (UNDP), Amman. http://www.undp.org/content/dam/jordan/docs/ Publications/Enviro/climate-changet-from\%20batir\%20smaller\%20version.pdf. Viewed 10 Aug 2015

MoEnv: Ministry of Environment, Ministry of Environment of Jordan and the United Nations Development Programme (MEJ-UNDP) (2009) Jordan's Second National Communication to the United Nations Framework Convention on Climate Change (UNFCCC), Amman-Jordan. Deposit No.: 2009/11/4731, Jordan Ministry of Environment: Amman. http://unfccc.int/resource/docs/natc/jornc2.pdf. Viewed 16 Oct 2013

Nash JE, Sutcliffe JV (1970) River flow forecasting through conceptual models. Part I-a discussion of principles. J Hydrol 10(3):282-290 pp. doi:10.1016/0022-1694(70)90255-6

Neitsch SL, Arnold JG, Kiniry JR, Srinivasan R, Williams JR (2005) Soil and Water Assessment Tool Theoretical Documentation, Version 2005. Temple: Grassland, Soil and Water Research Laboratory, Agricultural Research Service. http://swat.tamu.edu/software/swat-model/www.brc.tamus.edu/swat/ doc.html. Viewed 16 Oct 2013

Soil Conservation Service (SCS) (1972) National Engineering Handbook, Section 4, Hydrology. Chapters 7, 8, 9, and 10. U.S. Department of Agriculture, Washington, DC

Soil and Water Assessment Tool (SWAT) (2009) Soil and Water Assessment Tool: AVSWAT. Grassland, Soil and Water Research Laboratory, USDA-ARS. http://swat.tamu.edu/software/avswat/Available. http://swatmodel.tamu.edu/. Viewed 16 Oct 2013

Rakad A Ta" any, Awni T. Batayneh and Rasheed A. Jaradat (2007), Evaluation of groundwater quality in the Yarmouk Basin, North Jordan. J Environ Hydrol, vol 15. Paper 28 Nov 2007

Wang Z, Ficklin DL, Zhang Y, Zhang M (2012) Impact of climate change on streamflow in the arid Shiyang River Basin of northwest China. Hydrol Proces 26(18):2733-2744. doi:10.1002/hyp.8378 
Wilby RL, Dawson CW (2004) Using SDSM Version 3.1 - a decision support tool for the assessment of regional climate change impacts. User Manual. $67 \mathrm{pp}$. http://unfccc.int/resource/cd_roms/na1/v_and_ a/Resoursce_materials/Climate/SDSM/SDSM.Manual.pdf. Viewed 16 Oct 2013

World Bank (2013) Jordan Overview. Online document. http://www.worldbank.org/en/country/jordan/ overview. Viewed 16 Oct 2013 